\title{
Impact of oil price fluctuations on an energy-exporting economy: Evidence from Russia
}

\author{
Naoyuki Yoshino ${ }^{1}$, Victoriia Alekhina ${ }^{2, *}$ \\ ${ }^{1}$ Dean, Asian Development Bank Institute (ADBI), Tokyo, Japan \\ ${ }^{2}$ Master Candidate, Keio University, Tokyo, Japan
}

\section{Keywords:}

Energy economics Oil prices

Inflation targeting

Monetary policy

Received: 10 March 2016

Accepted: 10 July 2016

Published: 12 August 2016

\begin{abstract}
The oil prices have been falling recently and reached the record low level. This paper assesses the impact of crude oil price movements on two macro variables, the Gross Domestic Product (GDP) growth rate, and consumer price index inflation rate, in Russia. Russia is selected for this analysis because it is one of the world's largest oil exporters and oil revenue accounts for a significant portion of the country's government budget. The main objective of this study is to see and compare the response of the two macro-variables of Russia during the high oil price era with the low oil price era. The results obtained suggest that the impact of crude oil price movements on Russia's GDP growth rate in low oil prices era is much higher than in high oil price era. On the other hand, the impact of crude oil price movements on the consumer price index inflation was found to be milder in low oil price era. These results are obtained by examining the impact of oil price fluctuations on supply and demand side of the Russia`s economy.
\end{abstract}

(C) 2016 The Author(s). Published by TAF Publishing.

\section{INTRODUCTION}

Since the oil price shock of 1973, several studies have been pursued to show the impact of oil price fluctuations on the economy, such as (Hamilton, 1985; Barsky \& Kilian, 2004; Kilian, 2009). Significant increase in oil prices in 2001 and its sharp drop after the Lehman shock in 2008 have renewed interest in the impact of oil price movements on the macro-economy (Hamilton, 2009; Yoshino \& Taghizadeh-Hesary, 2014b). Several studies including Peersman \& Robays (2012), Yoshino \& Taghizadeh-Hesary

*Corresponding author: Victoriia Alekhina

E-mail: alekhinavic@gmail.com
(2015) have shown which economies benefited and which economies lost during the oil price shocks. Hamilton (1983) has found that economic slowdowns in the U.S. were actually consequences of oil shocks. Following the financial crisis of 2007-2008, oil prices started to grow again, but recently Brent crude oil experienced a sharp drop from US\$ 117.15 on September 6, 2014 to below US\$ 27.88 on January 20, 2016. Discussions on the relationship between oil prices and macro-economy have been renewed again. In this research, we assess the impact of oil price movements on the macro-economy of energy exporting country. And surprisingly, up to now only a few studies have been focused on Russia, which is currently 
the world`s second largest oil exporter where oil revenue accounts for a significant portion of the country's government budget. The purpose of this paper is to empirically estimate the effect of oil price movements on the two main Russian macroeconomic indicators: Consumer Price Index (CPI) inflation rate (by estimating aggregate supply side of economy) and the GDP gap growth rate (by estimating aggregate demand side). The paper develops both theoretical and the empirical analysis and addresses the following two questions. First, has the inflation rate in Russia been affected by the increase in energy prices?

Secondly, have increased revenues from rising price of natural resources affected the aggregate demand due to export boom in Russia? The structure of this paper is as follows: in the next section we will shed some light on the Russian economy and the crucial role of its energy sector. Then we will develop theoretical base and explain about the relationship between energy prices, general price level and economic growth by the aggregate demand and aggregate supply model. In the second section we will employ the Simultaneous Equations Model (SEM), empirical analysis is provided in the third section; in the fourth section, we will summarize our results.

\section{Overview of Russian Economy}

On December 26, 1991, Soviet Union was abolished and all the states including Russia became independent. Because of such an immediate transition, economic indicators have drastically declined. Inflation reached its peak of 2333.30 percent in 1992 and exchange rate dropped in old denomination from 144 Russian Rubles per US\$ in July, 1992 to nearly 5.000 Rubles per US\$ in October, 1995. Real GDP has declined by nearly half by 1999 . Under the leadership of new government of Boris Eltsin, two main targets were set up stabilization and transition to the market-based economy.

However, country was suffering from shortage in foreign direct investment and domestic capital, therefore after price control was finally lifted in 1998, Russia has experienced hyperinflation and dollarization of the economy following the Russian financial crisis. Sharply falling oil prices also contributed to the crisis since Russian revenues coming from oil exports started to decline and government budget was suffering from deficit. Finally, government devalued Russian Ruble and defaulted on the debt. The Vladimir Putin government came into power in 2000, and a number of economic reforms were implemented in order to help the economy. High priority was given to low-income earners and pensions since they dropped nearly by half after the financial crisis. The new government has advocated liberal economic reforms introducing the new taxation policy with comparatively lower tax rates (for example corporate tax rate was reduced from 34 to 25 percent), and new optional tax system for Small-Medium Enterprises (SME). The overall tax burden became lower.

Also, the number of state owned companies were established in sectors, which are strategic for the Russian economy and expected to contribute to the economic growth. Therefore, such companies as Gazprom and Rosneft (energy producing companies) and Oboronpron (aerospace holding company) have emerged and 50 percent or more owned by the Russian government still remaining the most effective and competitive companies on both the domestic and world markets. Under Vladimir Putin`s presidency, Russian economy has improved significantly.

In 2004 was established the Stabilization fund, which accumulated a portion of oil revenues and invested in foreign government bonds. Due to proper investment by 2005, Russia could repay the foreign debt accumulated by Soviet Union. In 2014, Russia`s debt to GDP ratio was about 10 percent which is one lowest among world economies. In 2008, the fund was split into two parts Reserve Fund and National Welfare Fund. The first one, which was designed in order to prevent the economy from the global financial shocks by investing in safe assets, was given 3.058 billion of Russian Rubles (US\$ 125 billion).The second one, which was created to guarantee the pensions of the citizens by to investing in risky assets with high return, was given 783 billion of Russian Rubles (US\$ 32 billion).

The overall amount of the Stabilization Fund accounted for 3.645 billion of Russian Rubles (US\$ 90 billion) in 2014 (Ministry of Finance of Russian Federation, 2015). In the Figure 1, we can see Russia`s GDP growth rate in 2000s. It is clear that between 2000 and 2008, it was rapidly increasing, however sharply dropped during the Lehman crisis.

The global economic downturn has resulted in the shock to Russian economy. Following the financial crisis of 20072008, a decline in global demand for crude oil caused oil prices to drop from US\$ 133.11 in July 2008 to below US\$ 42.01 in December 2008 (Yoshino \& TaghizadehHesary, 2014b). It caused significant negative effect on the Russian economic growth. However due to effective economic measures implemented by the government, 
economy recovered immediately after crisis and in 2014, Russian economy became number five in the world by
Purchasing Power Parity (PPP) according to (World Bank, 2015) estimation.

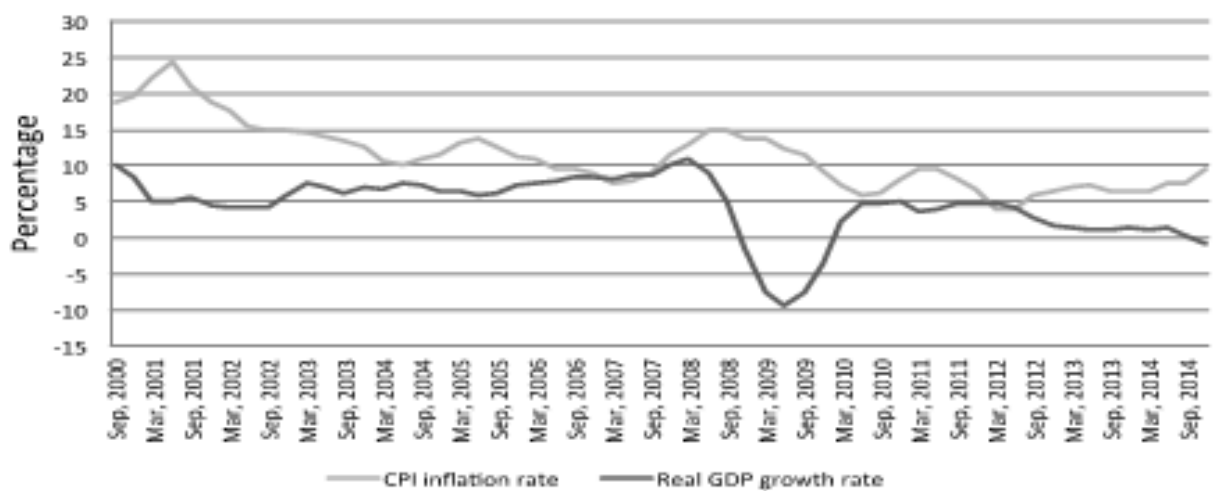

Source: International Financial Statistics, IMF

FIGURE 1. Russia`s GDP growth rate and CPI inflation rate 2000-2014

In order to maintain widely fluctuating exchange rate against the US dollar in 2005, financial authorities introduced basket exchange rate. The basket consisted of US dollar and euro and due to increasing amount of foreign reserves coming from export of natural resources; government could maintain stability of exchange rate by intervening to the market. Exchange rate, however, has shown high dependence from world prices on energy products. For example, Ruble has appreciated by nearly 27 percent from December 2002 to July 2008-during the period of rapid growth of energy prices, when Brent crude oil prices rose from US\$28.33 to US\$ 132.72. Appreciating exchange rate was one of the reasons of the relatively high inflation in Russia in 2000s (Figure 1), since government was trying to control the exchange rate together with inflation targeting. The lowest inflation rate was achieved in April 2012 (3.58 percent) but started to increase immediately after that and government has decided to switch to free float exchange rate regime from 2015 focusing on the inflation target of 4 percent. However, the target of 4 percent has never been achieved; moreover it increased to nearly 12 percent in 2015.

\section{Russia`s Energy Policy}

Russian Federation is non-OPEC energy exporting economy. According to Energy Information Administration (2015) report, currently Russia is the world's largest producer of crude oil and the second largest producer of dry natural gas (after the U.S.). Also, Russia is the one of world`s largest coal producers (Energy Information Administration, 2015). The export of natural resources and its products play a crucial role for the country`s economy. Moreover, the price of the most common export crude oil grade-Urals blend are determined according to price of Brent crude on London market, so the world's energy prices have direct effect on the Russia`s revenues coming from energy export. The figure below shows the world`s biggest crude oil suppliers. As it is clear, the largest exporter was the Soviet Union, however after it was abolished in 1991, the daily production has sharply dropped from 9 to 6 million barrels per day, making Russia third after U.S and Saudi Arabia (International Energy Statistics, 2011). Later Russia`s level of crude oil supply gradually increased and reached the second highest spot after Saudi Arabia. Currently Russia produces more than 10 million barrels of crude oil every day (International Energy Statistics, 2011). According to U.S. Energy Information Administration, in year of 2013, the export of crude oil, petroleum products and natural gas has shared 68 percent of total export and was accounted for nearly 356 billion of U.S. dollars. Of the 68 percent, 33 percent (US\$ 174 billion) was for crude oil mostly exported to Europe and some Asian countries; 14 percent (US\$ 73) was for natural gas mostly exported to Europe; 21 percent (US\$ 109) was for petroleum products, which was exported mostly to Europe and some to North America (Energy Information Administration, 2015). According to Energy Information Administration (2015), in 2014 more than 70 percent of crude oil and more than 90 percent of natural gas were exported to Europe, so we can say that Russia is dependent on Europe in terms of energy export. Export of hydrocarbons is crucial for Russian economy since oil and gas revenues account for almost half of the total federal budget revenues. As it is clear inthe diagram 
below, in 2015 oil and gas extraction tax and its export duties accounted for nearly 45 percent, making the share of income from natural resources the biggest in total budget revenues. Also, revenues from oil and gas sales contribute to the amount of foreign reserves, which have shared the largest part (61 percent) in total assets of Russia`s Central Bank in 2015.

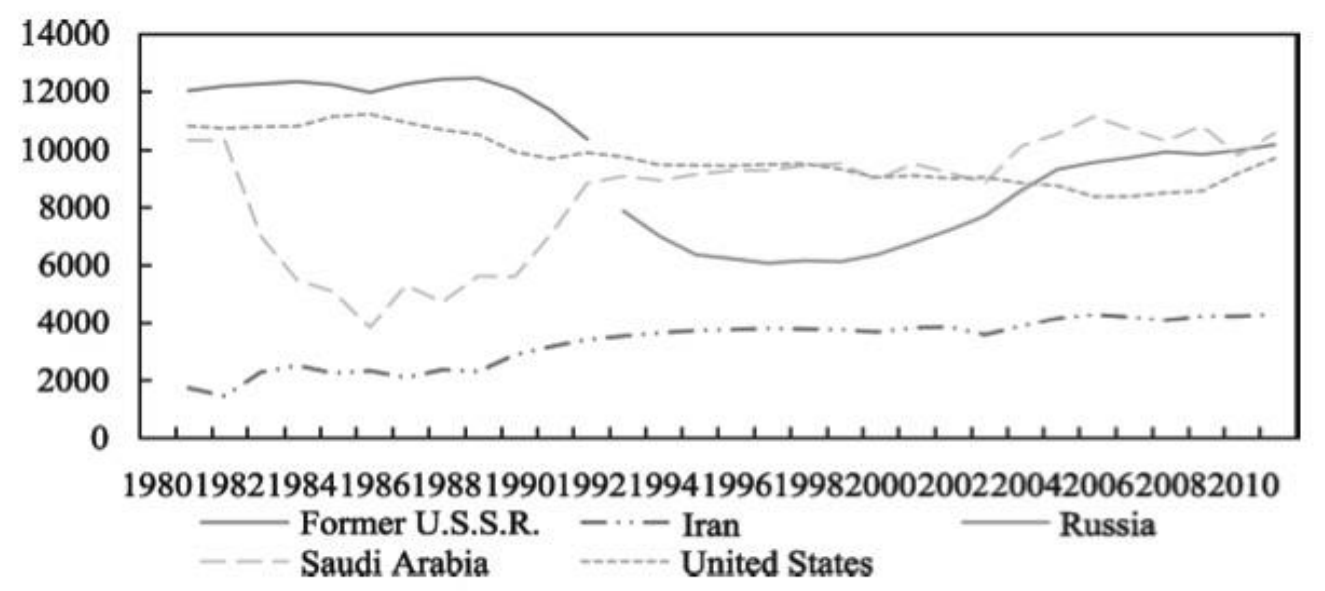

Source: Taghizadeh, Yoshino, Abdoli \& Farzinvash, (2013)

FIGURE 2. World crude oil supply by country 1980-2010

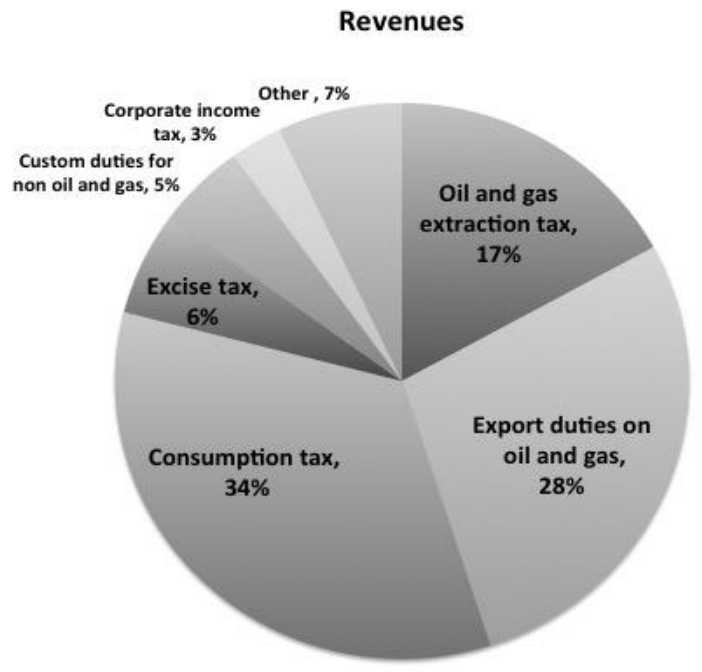

Source: Ministry of Finance of Russian Federation (2015)

FIGURE 3. General account budget for FY 2015

Therefore, during the period of oil prices' rapid growth, the amount of foreign reserves accumulated in Russia increased significantly due to trade surplus. Since exchange rate regime was set up as basket consisting of dollar and euro, it became much easier for the government to intervene with the foreign exchange market and the Russian Ruble has appreciated. Lehman crisis of 2008-
2009 decreased world activity and energy demand, making Russia to suffer from shortfalls of foreign reserves coming from oil exports. As a result, Ruble exchange rate significantly depreciated, CPI inflation rate has increased and the GDP growth has slowed down, however the economy recovered immediately after that. Recent oil price drop showed again how important world energy 
prices for Russian economy were-Brent crude oil dropped below US $\$ 30$ in 2016 and Ruble depreciated by more than GDP growth rate is expected to be negative in 2016. So we can see that Russian economy responds to energy price shocks similarly. But does the inflation really increase and output shrinks because of the decreased energy prices? We are going to discuss it in the next sections.

\section{Relationship between Energy Prices and Macro- Economy}

In general theory of energy economics, oil has been considered as the main economic growth driver. Oil and its products are widely used not only as energy source but also for transportation, as an intermediary resource and for many other purposes. Therefore oil has been
50 percent. Inflation has increased to more than 12 percent and according to World Bank (2015) estimation, considered as one of the most important production inputs together with capital and labor. Since oil is crucially important but has limited input, its equilibrium price has been determined as marginal cost of production added to its scarcity rent, according to Hotelling (1931). Moreover as economics history shows, energy prices are dependent on different factors: economic, political and monopoly. The impact of oil price fluctuations on the macro-economy was concluded to be significant in most of the cases, and has been emphasized in Hamilton (1996). However numerous studies found that not all economies are affected in the same way by oil price shocks (Hamilton, 2003).

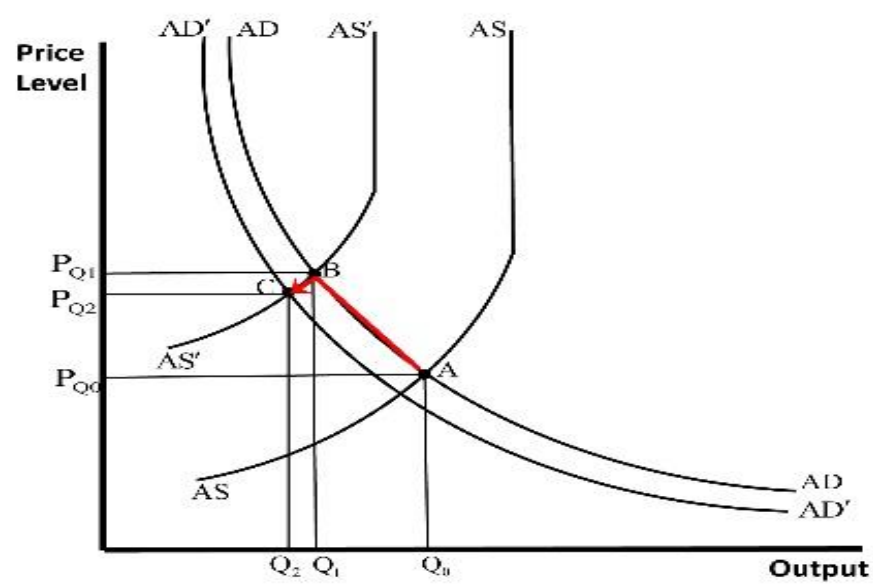

Source: Yoshino \& Taghizadeh-Hesary (2015)

FIGURE 4. How higher energy prices can create inflation

Due to its importance, world energy prices can affect main macroeconomic indicators such as inflation and output growth rates. Those relationships have been emphasized in (Taghizadeh-Hesary \& Yoshino, 2013, 2014) and (Yoshino \& Taghizadeh-Hesary, 2015) on the example of Japanese economy by a simple Aggregate Demand (AD)-Aggregate Supply (AS) model (Figure 4). We can see on the figure below the point $A$, which is initial equilibrium of price PQ0 and output Q0. If we assume that price of oil increases, it will cause hike of other energy carriers` price (Energy Information Administration, 2015) and AS curve will decrease to AS since production becomes more expensive. Therefore general price level rises to PQ1 and output level shrinks to Q1; the economy moves to disequilibrium point B. On the other hand, increased oil prices will decrease demand for it and consumption will shrink. It will directly affect the demand side of the whole economy since oil is one of the main production inputs, therefore $\mathrm{AD}$ curve will shift down to $\mathrm{AD}$ '. When the aggregate demand declines, the price level goes down as well and output level goes up to PQ1 and Q1 respectively. Economy moves to final equilibrium point, which is point $\mathrm{C}$. Although, the point $\mathrm{C}$ is the new equilibrium, the economy may adjust to oil price movement with some lag, due to the lack of information or other factors. In the next section of our paper, we are going to estimate this theory empirically on the example of Russia, which currently the second largest oil exporter in the world. We can see the relationship of oil prices and inflation inthe Figure 5. The left scale is Russia`s average producer price of oil in Russian Rubles per ton and the right scale is CPI inflation rate in percent. It is clear that these two indicators follow a similar path. The inflation 
rate was quite high in early 2000s right after the Russian financial crisis, but high oil demand of 2008 pushed oil prices up making inflation rate to rise significantly in Russia. On the other hand, the Lehman crisis led oil prices to collapse, and we see that inflation rate became much milder right after that. And recently we can observe association between these two variables as well; however inflation rate has been maintained on a comparatively low level due to aim proved monetary policy provided by the Russian government.

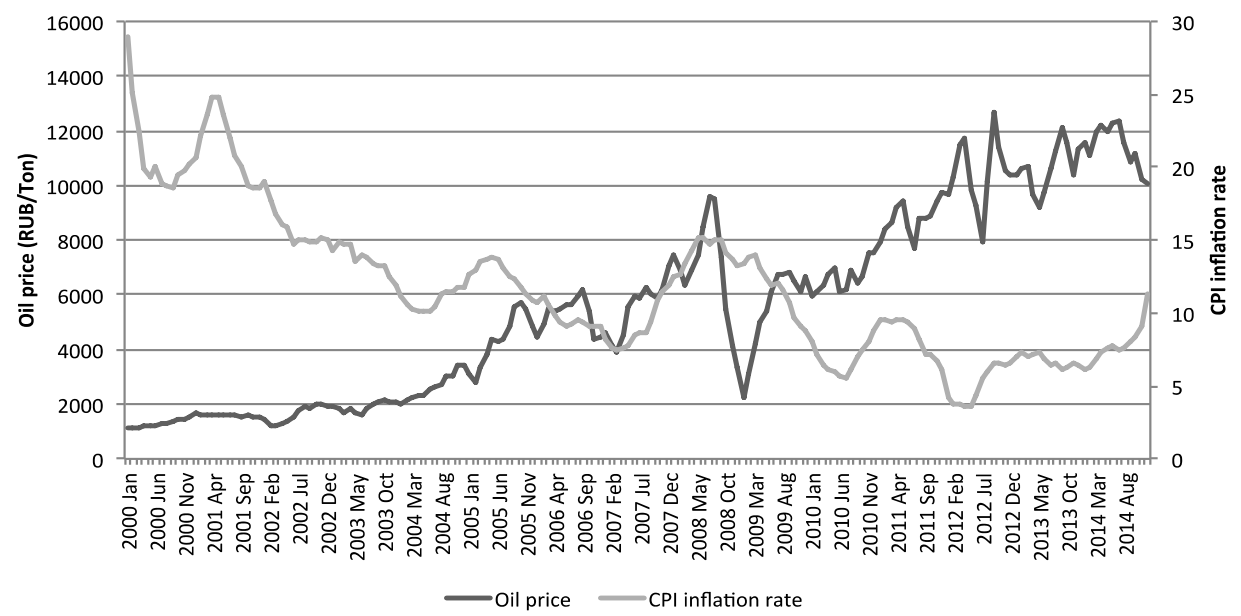

Source: Federal State Statistics Service

FIGURE 5. Oil price and inflation rate in Russia

\section{MODEL}

In this section we will employ a model to estimate the impact of energy price fluctuations on Russia`s macro economy. The aim is to answer the following two questions (i) has the inflation rate in Russia been affected by the monetary policy implemented by the Central Bank of Russia (CBR) or are there other reasons for the increase in inflation rate, such as increasing energy prices, and secondly (ii) have increased revenues from natural resources exporting affected the output growth rate in Russia?

In order to answer to these questions we should look on the supply and demand side of the economy. As we mentioned earlier, energy, especially oil and gas are considered as one of the mail production factors together with labor and capital. Therefore on the economy`s supply side we will have a production function, which is consists of three elements: labor, capital and energy:

$Q_{t}=\left(L_{t}\left(\frac{W_{t}}{P_{Q t}}, Q_{t}\right), K_{t}\left(i_{t}, Q_{t}\right), E_{t}\left(\frac{P_{E t}}{P_{Q t}}, Q_{t}\right)\right)$

Where Qt is total output, Lt is labor input, Et is energy input, $\mathrm{Wt}$ is wage rate, it is interest rate, $\mathrm{PQ} t$ is Consumer Price Index (CPI) and PEtis energy price. There are direct relationships between three elements and total output level, moreover, the equation above shows how these factors can change the total output level. In other words, an increase in labor, capital or energy will lead to rise in output. However, the amount of input of each element has negative relationships with its price, therefore, the more expensive the input, the lower consumption of it, the lower will be the output. In case of Russia, the energy (oil and gas) producing companies crucially contribute to the economy. Therefore, we can measure the total supply as the sum of supply from energy producing companies and non-energy producing companies:

$Q_{t}=Q_{t}^{\gamma}+Q_{t}^{\lambda}$

Where is total supply, is supply coming from energy producing company, is supply coming from non-energy producing company. Therefore, we will have two output equations, first is for energy producing company, which needs input of capital and labor to produce its output (oil and gas):

$$
Q_{t}^{\gamma}=f\left(L_{t}^{\gamma}\left(\frac{W_{t}}{P_{Q_{t}}}, Q_{t}\right), K_{t}^{\gamma}\left(i, Q_{t}\right)\right)
$$


and supply of non-energy producing company, which depends on labor price, capital price and prices of oil and gas which are and respectively:

$Q_{t}^{\lambda}=f\left(L_{t}^{\lambda}\left(\frac{W_{t}}{P_{Q_{t}}}, Q_{t}\right), K_{t}^{\lambda}\left(i, Q_{t}\right), E_{\text {oil }}^{\lambda}\left(\frac{P_{o i l t}}{P_{Q_{t}}}, Q_{t}\right), E_{\text {gast }}^{\lambda}\left(\frac{P_{\text {gast }}}{P_{Q_{t}}}, Q_{t}\right)\right)$

Summarizing two equations above, we will get the aggregate supply equation:

$Q_{t}=\alpha_{\mathrm{o}}+\alpha_{1} E_{t}\left\{\pi_{t-1}\right\}+\alpha_{2} K_{t}+\alpha_{3} p_{\text {oil }}+a_{3} p_{\text {gas }}$

Where is total supply, is expected inflation rate, is capital price, and are oil and gas price respectively. On the other hand, aggregate demand equation will be as follows:

$Q_{t}=C_{t}\left(Q_{t}, P_{E_{t}}\right)+I_{t}\left(i, P_{E_{t}}\right)+G_{t}\left(Q_{t}, P_{E_{t}}\right)+E X_{t}\left(e_{t}, P_{E_{t}}\right)-I M_{t}\left(e_{t}, Q_{t}\right)$

Where is consumption, is investment, is government spending, and are export and import volumes respectively. It should be noted that in case of Russia`s economy energy prices must be included in the demand equation as well as in the supply equation. As we mentioned before, Russia is a large energy exporter, where 68 percent of total export were for oil, gas and petroleum products and moreover around 50 percent of government budget revenues came from extraction and export of energy resources in 2013 (Energy Information Administration, 2015). Therefore, the amount of consumption, investment, government spending and total demand crucially depends from revenues coming from energy exports. As we mentioned inthe previous section, energy price shocks affect inflation rate and total output, i.e. aggregate supply and aggregate demand.

The framework for the analysis of the energy price movement on the macro economy was very well emphasized in (Yoshino \& Taghizadeh-Hesary, 2015) on the example of energy importing country (Japan) through New Keynesian approach which includes aggregate supply (Phillips Curve) equation and aggregate demand equation. For our empirical analysis we will use the SEM framework, developed in (Yoshino \& Taghizadeh-Hesary, 2015). In order to capture the estimation for an energy exporting country (Russia) we modify the model by including energy prices (oil and gas) to the demand equation, since revenues coming from natural resources export have a direct effect on both sides of the economy. To estimate the effect of oil and gas price on the supply and demand side of the economy we employ simultaneous equations model (SEM) which is consists of two equations below. According to Yoshino \& Taghizadeh-Hesary (2015), first equation is for Phillips Curve (Galí and Gertler, 2007; Gali, 2008), which represents firms' price decisions along with marginal costs and activity level (Galí, 2008), (Galí \& Gertler, 2007)). The first equation is as follows (7):

$\pi_{t}=\alpha_{\pi} E_{t}\left\{\pi_{t-1}\right\}+\alpha_{y}\left(y_{t}-\overline{y_{t}}\right)+\alpha_{\text {oil }} p_{t}^{o i l}+\alpha_{\text {gas }} p_{t}^{\text {gas }}$

Where is inflation rate, is expected inflation rate, is s GDP gap represents deviations of (log) output from (log) steady state (or trend level), , are respectively crude oil prices and natural gas prices. We must have prices of both of these energy carriers because both of them are important for Russia`s economy and could have an effect on the price level and aggregate supply. The second part of the SEM is demand equation (8), relates to output gap which is negatively affected by the real interest rate and exchange rate, positively by the lagged output gap (expected gap), oil price and gas price .

$$
\begin{gathered}
\left(y_{t}-\bar{y}_{t}\right)=-\frac{1}{\beta_{i}}\left(i_{t}^{L M}-E_{t}\left\{\pi_{t-1}\right\}\right)+\beta_{y} E_{t}\left\{\left(y_{t-1}-\bar{y}_{t-1}\right)\right\} \\
-\beta_{e} e_{t}+\beta_{o i l} p_{t}^{o i l}+\beta_{\text {gas }} p_{t}^{\text {gas }}
\end{gathered}
$$

Our simultaneous equations finally resulting to AS-AD model (9):

$\pi_{t}=\alpha_{\pi} E_{t}\left\{\pi_{t-1}\right\}+\alpha_{y}\left(y_{t}-\bar{y}_{t}\right)+\alpha_{o i l}$ oil $+a_{g a s} p_{t}^{\text {gas }}$
$\left(y_{t}-\bar{y}_{t}\right)=-\frac{1}{\beta_{i}}\left(i_{t}^{L N}-E_{t}\left\{\pi_{t-1}\right\}\right)+\beta_{y} E_{t}\left\{\left(y_{t-1}-\bar{y}_{t-1}\right)\right\}-\beta_{e} e_{t}+\beta_{o i l} p_{t}^{o i l}+\beta_{g a s} p_{t}^{\text {gas }}$

Which enables us to estimate the effect of energy (oil and gas) price fluctuations on inflation rate and output gap of the natural resources exporting economy (i.e. Russia)?

\section{EMPIRICAL ANALYSIS}

\section{Data Description}

In order to estimate our model, we will use monthly data from January 2000 to December 2014 (180 observations). This period was chosen for analysis for two reasons: (i) from 2000, Russia`s economy has stabilized and showed significant growth after Russian financial crisis, as we explained in the first section of our paper, and (ii) this period contains both - the era of high oil prices before global financial crisis and era of relatively low oil prices after that. The estimation of this particular period enables us to see how Russia`s economy responds to sharp increase and drop of energy prices, therefore we separate the estimation into two periods: January 2000 to July 
2008 -high oil prices era and August 2008 to December 2014 - low oil prices era. The data we used for our analysis areas follows: For inflation rate, we used growth rate of consumer price index (CPI), for expected inflation, we used lagged value of CPI, output gap was calculated as deviation of the real GDP of its trend level (GDP in a situation of full employment) and for expected gap, we used its lagged value (Hodrick \& Prescott, 1997). For crude oil and natural gas prices, we used average producer prices, in Russian Rubles per ton and Rubles per 1000 cubic meters respectively. As for the long-term interest rate, we used Central Bank lending rate, and finally for the exchange rate, the real effective exchange rate was used. The data for our analysis are from International Financial Statistics (IFS) of IMF, the Central Bank of Russia Federation (CBR) database and Federal State Statistics Service database.

\section{EMPIRICAL RESULTS}

In order to estimate our model, we will use Seemingly Unrelated Equations (SUE) method, which is common for SEM estimation statistical technique implying the use of instrumental variables. However, before we run the regressions on our model, we should check if SEM is identified or not (Yoshino \& Taghizadeh-Hesary, 2015).

TABLE 1. Empirical results

\begin{tabular}{|c|c|c|c|c|}
\hline & Notation & $\begin{array}{l}2000 \mathrm{~m} 1- \\
2014 \mathrm{~m} 12\end{array}$ & $\begin{array}{l}2000 \mathrm{~m} 1- \\
2008 \mathrm{~m} 7\end{array}$ & $\begin{array}{l}2008 \mathrm{~m} 8- \\
2014 \mathrm{~m} 12\end{array}$ \\
\hline \multicolumn{5}{|l|}{$\begin{array}{l}\text { Phillips Curve } \\
\text { Inflation Rate }\end{array}$} \\
\hline Lagged inflation rate & $E_{t}\left\{\pi_{t-1}\right\}$ & $0.52(6.68)^{* * *}$ & $0.41(4.25)^{* * *}$ & $0.70(5.73)^{* * *}$ \\
\hline GDP gap & $\left(y_{t}-\overline{y_{t}}\right)$ & $-0.01(-0.91)$ & $0.01(1.20)$ & $0.01(0.69)$ \\
\hline Crude oil price & $p_{t}^{o i l}$ & $-0.01(-0.37)$ & $0.02(1.85)^{*}$ & $-0.01(-1.30)$ \\
\hline Gas price & $p_{t}^{g a s}$ & $-0.01(-2.09)^{* *}$ & $-0.01(-1.58)^{*}$ & $0.02(2.09)^{* *}$ \\
\hline R-squared & & 0.31 & 0.32 & 0.49 \\
\hline $\begin{array}{l}\text { Durbin-Watson Statistic } \\
\text { Aggregate Demand } \\
\text { GDP gap }\end{array}$ & & 1.96 & 1.96 & 1.67 \\
\hline Long-term real interest rate & $i_{t}^{L N}-\pi$ & $-0.40(-1.02)$ & $-0.75(-1.41)$ & $-0.47(-1.22)$ \\
\hline Lagged GDP gap & $\frac{\left(y_{t-1}-\right.}{\left.y_{t-1}\right)}$ & $0.67(3.75)^{* * *}$ & $0.89(4.06)^{* * *}$ & $2.51(4.76)^{* * *}$ \\
\hline Exchange rate & $e_{t}$ & $-0.16(-0.91)$ & $-1.12(-2.47)^{* *}$ & $-0.13(-1.12)$ \\
\hline Crude oil price & $p_{t}^{o i l}$ & $0.07(1.78)^{*}$ & $0.10(0.48)$ & $0.11(3.81)^{* *}$ \\
\hline Gas price & $p_{t}^{g a s}$ & $0.08(1.57)$ & $0.12(1.86)^{*}$ & $-0.07(-1.44)$ \\
\hline R-squared & & 0.35 & 0.46 & 0.57 \\
\hline Durbin-Watson Statistic & & 2.07 & 2.11 & 1.88 \\
\hline
\end{tabular}

Notes: T-statistics are in parentheses. * indicates significance at $10 \% . * *$ indicates significance at $5 \% . \quad * * *$ indicates significance at $1 \%$. The Durbin-Watson statistic is used to test for the presence of autocorrelation.

For our model to be identified, we need to have enough instrumental variables for econometric analysis. To meet this requirement, we will consider oil and gas prices as exogenous (Revankar \& Yoshino (1990)) variables and assume that they are determined by their lagged values (Akaike, 1973) and include them into the model as instruments. Therefore we have enough exogenous variables, our model is identified, and we can start 
estimation of the SEM. For our analysis, we used variables in the first differences form, since performed Dickey-Fuller test showed that all variables converted to the first order are stationary, since the bull hypothesis of unit root was rejected. The results of the estimation are shown in Table 1. As we mentioned earlier, our analysis consists of two blocks-aggregate supply or Phillips curve and demand curve; and two periods-high oil price era (2000-2008) and relatively low oil price era (2008-2014). Graphically, y-axis of Phillips curve is inflation rate and $\mathrm{x}$-axis is GDP gap, so supply curve is upward sloping, means there are positive relationships between these two variables. The results we have got for Russia are in accordance with the theory for both periods, however there is no significant effect of GDP gap on the price level, which means that inflation rate is caused by factor other than GDP gap during the whole period.

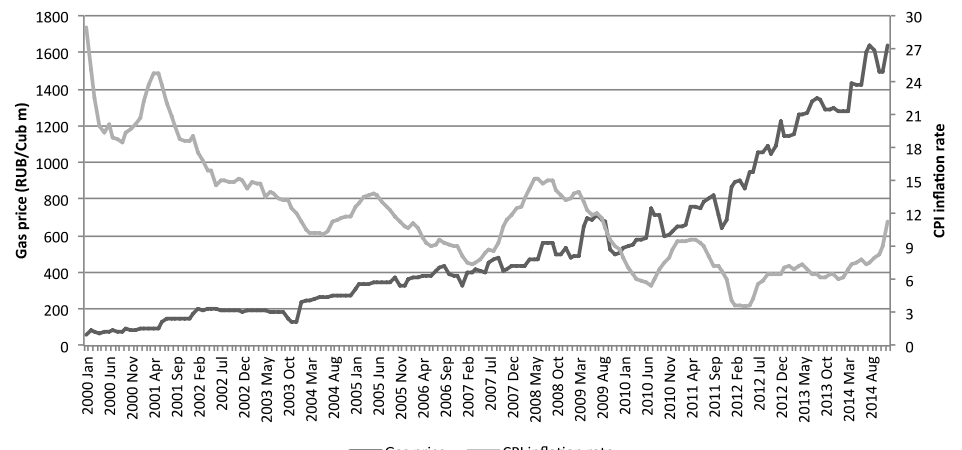

Source: Federal State Statistics Service

FIGURE 6. Gas price and inflation rate in Russia

On the other hand, lagged inflation rate had very significant positive impact on current inflation rate in both periods. It means that when economy is suffering from inflation, everyone is assuming that the level of price will also increase in near future; therefore it will accelerate inflation to rise even more. The crude oil prices and gas prices have opposite signs for two periods -oil is positive and significant for the first period (high oil prices era) and non-significant for the second period (low oil prices era). These results are in accordance with the theory we described in section 1.3 -when oil price experiences positive shock, it pushes up production costs, since currently oil is the major production input, therefore the general price level tends to increase. Interestingly, gas prices have opposite sign -negative for first period and positive for second. This finding is in accordance with what happened to natural gas price fluctuations. For oil prices, we consider period of 2000 to 2008 as a rapid growth period. On the other hand, for gas prices period of early 2000 s is era of comparatively low prices. Also, gas prices did not experience significant drop during the Lehman crises and in 2009 their growth accelerated significantly (Figure 6).Therefore, we can conclude that inflation which has been an issue for Russian economy was mostly created by rapidly growing energy prices of oil in pre-crisis period and of gas in post-crisis period.

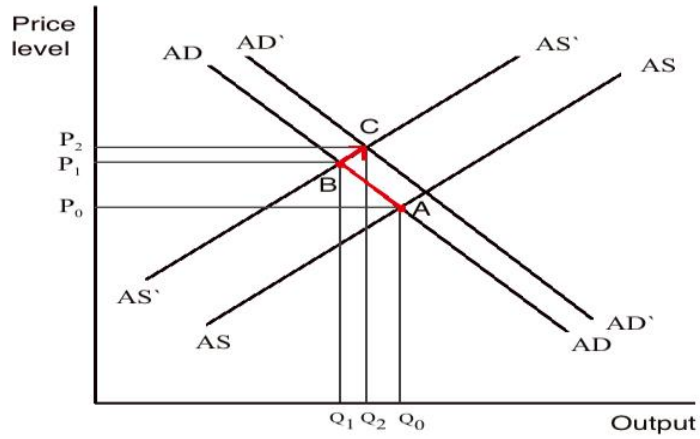


FIGURE 7. Impact of higher energy prices on the Russian economy

The second block of our analysis is aggregate demand side shown in the last part of Table 1. Decline in interest rate boosts the investment; therefore aggregate demand should improve, so the negative sign of long-term real interest rate in our results is correct for both periods but insignificant. The expected GDP gap has very significant positive relationship with current one. Exchange rate has an impact on the trade balance, i.e. on import and export. Russian Rubble was strongly appreciated during the period of high oil price growth due to large bulk of accumulated foreign reserves. However, when Rubble appreciates, it makes export of Russian products (i.e. natural recourses) more expensive and demand for them drops, therefore exchange rate has negative sign in both periods. Lastly, we can say that Russia benefits from lower energy prices since in the era of comparatively low prices of oil and those for gas, the GDP gap was significantly positively affected, and in the era of high prices for both energy carriers, the output gap was not significantly affected by any of these factors.

This can be explained by the fact that the higher prices of energy carriers make it difficult to export to other countries, therefore Russia`s trade balance deteriorates and government budget suffers from deficit. Moreover Russia is not only major exporter, but also has a noticeable domestic consumption of energy resources: interms of units, it consumes domestically more crude oil and natural gas than exporting abroad (Energy Information Administration. 2015). Therefore rapid growth of energy prices is unfavorable for the economy.

In the figure above, we can see AD and AS curves and equilibrium point $A$. When energy price is growing rapidly in Russia, it pushes up the cost of production and inflation rate, therefore initial price level P0 increases to P1; at the same time, output level remains same or declines to Q1, due to more expensive production factors and finally supply curve shifts to AS'. On the other hand, aggregate demand will be slightly pushed up due to increased revenues from export of natural resources, increasing therefore price level even more to P2 and pushing back output level to Q2. The mechanism of the shifts of AD and AS curves under the high energy prices in oil exporting country is shown in the Figure 7.

As was concluded by Yoshino \& Taghizadeh-Hesary (2014a) and proved by our theoretical framework followed by empirical estimation, the impact of oil price movements is different depending on the type of the economy: developed or emerging. We have found that for Russia`s economy, slowly growing energy (oil and gas) prices are more beneficial rather than rapidly growing ones. High energy prices accelerate domestic inflation because Russia is (i) a large consumer of energy and (ii) one of the major importers of consumer goods in the world. Therefore by exporting expensive oil and gas, it imports inflation. For the GDP growth, high oil prices are not optimal, because when Russia receives more foreign revenues from export of energy, its domestic currency appreciates, making other export goods expensive for other countries. Therefore, Russia`s trade partners substitute away from Russian goods, what reduces Russian export and output.

\section{CONCLUSION}

In this paper, we estimated the effect of oil and gas price fluctuations on the energy exporting economy, i.e. Russia through the period of January 2000 to December 2014, which contains both - the rapid growth and relatively slow growth for the two energy carriers. Our empirical results suggest that relatively higher energy prices affect inflation rate in Russia positively and significantly. However, it doesn't have any significant impact on the output level. On the other hand, when the growth rate of energy prices is comparatively slow, the inflation rate slows down and output level significantly increases. Therefore for energy (oil and gas) exporting economy for the stable growth in the long run and optimal inflation rate, relatively slow growth of energy prices would be more favorable rather than rapid growth.

\section{REFERENCES}

Akaike, H. 1973. Information theory and an extension of the maximum likelihood principle. Paper presented at the: Second International Symposium on Information Theory, Budapest, Hungary.

Barsky, R.B., \& Kilian, L. 2004. Oil and the macro economy since the 1970s. The Journal of Economic Perspectives, 18(4): 115-134. DOI: $10.1257 / 0895330042632708$

Energy Information Administration. 2015. Russia's energy report U.S energy information administration, URL: https://goo.gl/vfMxkW. Last access on 28 July 2015. 
Galí, J. 2008. Monetary policy, inflation, and the business cycle: An introduction to the new Keynesian framework. New Jersey, NJ: Princeton University Press.

Galí, J., \& Gertler, M. 2007. Macroeconomic modeling for monetary policy evaluation. The Journal of Economic Perspectives, 21(4): 25-45. DOI: 10.1257/jep.21.4.25

Hamilton, J.D. 1983. Oil and the macroeconomy since World War II. The Journal of Political Economy, 91(2): 228-248. DOI: $10.1086 / 261140$

Hamilton, J.D. 1985. Historical causes of postwar oil shocks and recessions. The Energy Journal, 6(1): 97-116. D0I: 10.5547/ISSN0195-6574-EJ-Vol6-No1-9

Hamilton, J.D. 1996. This is what happened to the oil price-macroeconomy relationship. Journal of Monetary Economics, 38(2): 215-220. DOI: 10.1016/S0304-3932(96)01282-2

Hamilton, J.D. 2003. What is an oil shock? Journal of Econometrics, 113(2): 363-398. D0I: 10.1016/S03044076(02)00207-5

Hamilton, J.D. 2009.Causes and consequences of the oil shock of 2007-08. Working Papers no. 215-283, Economic Activity Economic Studies Program, The Brookings Institution Massachusetts, Massachusetts, MA.

Hodrick, RJ., \& Prescott, EC. 1997. Postwar US business cycles: An empirical investigation. Journal of Money, Credit, and Banking, 29(1): 1-16.

Hotelling, H. 1931. The economics of exhaustible resources. The Journal of Political Economy, 39(2): 137-175. D0I: $10.1086 / 254195$

nternational Energy Statistics. (2011). URL: http://goo.gl/LxMNBc. Last accessed on 25 July 2016.

Kilian, L. 2009. Not all oil shocks are alike: Disentangling demandand supply shocks in the crude oil market. American Economic Review, 99(3): 1053-1069. D0I: 10.1257/aer.99.3.1053

Ministry of Finance of Russian Federation. (2015). URL: http://minfin.ru/ru/. Last accessed on 25 July 2016.

Peersman, G., \& Van Robays, I. 2012. Cross-country differences in the effects of oil shocks. Energy Economics, 34(5): 1532-1547. DOI: 10.1016/j.eneco.2011.11.010

Revankar, N.S., \& Yoshino, N. 1990. An expanded equation'approach to weak-exogeneity tests in structural systems and a monetary application. The Review of Economics and Statistics, 72(1): 173-177. D0I: 10.2307/2109757

Taghizadeh-Hesary, F., \& Yoshino, N. 2013. Which side of the economy is affected more by oil prices: Supply or demand? Working paper no. 13-139, United States Association for Energy Economics (USAEE), Cleveland, OH.

Taghizadeh-Hesary, F., \& Yoshino, N. 2014. Monetary policies and oil price determination: An empirical analysis. OPEC Energy Review, 38(1): 1-20. DOI: 10.1111/opec.12021

Hesary, F.T., Yoshino, N., Abdoli, G., \&Farzinvash, A. 2013. An estimation of the impact of oil shocks on crude oil exporting economies and their trade partners. Frontiers of Economics in China, 8(4): 571-591.

World Bank. 2015. World Bank Open Data: GDP growth (annual \%). URL: http://goo.gl/7k8lxt Last accessed on 22 July 2016.

World Bank. 2015. World development indicators database: Gross domestic product 2014 PPP. URL: http://goo.gl/Wx3BWO. Last accessed on 22 July 2015.

Yoshino, N., \& Taghizadeh-Hesary, F. 2014a. Economic impacts of oil price fluctuations in developed and emerging economies. IEEJ Energy Journal, 9(3): 58-75.

Yoshino, N., \& Taghizadeh-Hesary, F. 2014b. Monetary policy and oil price fluctuations following the subprime mortgage crisis. International Journal of Monetary Economics and Finance, 7(3): 157-174. DOI: 10.1504/IJMEF.2014.066482

Yoshino, N., \& Taghizadeh-Hesary, F. 2015. Effectiveness of the easing of monetary policy in the Japanese economy, incorporating energy prices. Journal of Comparative Asian Development,14(2): 227-248. D0I: $10.1080 / 15339114.2015 .1059059$

— This article does not have any appendix. - 